\title{
The Importance of Ideas: An A Priori Critical Juncture Framework
}

John Hogan,

School of Law and Government, Dublin City University,

Glasnevin,

Dublin 9,

Ireland

Email: john.hogan2@mail.dcu.ie
David Doyle,

School of Law and Government, Dublin City University,

Glasnevin,

Dublin 9,

Ireland

Email: david.doyle@dcu.ie

Acknowledgement: We would like to thank Professor Robert Elgie for helpful comments during the writing of this article, as well as the Canadian Journal of Political Science's anonymous reviewers, for all of their suggestions.

Dedication: This article is dedicated to the memory of Dr. Peter Fitzgerald, a valued friend and colleague, missed by all.

\begin{abstract}
This paper sets out an improved framework for examining critical junctures. This framework, while rigorous and broadly applicable, already an advance on the frameworks currently employed, primarily seeks to incorporate an a priori element. Until now the frameworks utilised in examining critical junctures were entirely postdictive. Adding a predictive element to the concept will constitute a significant advance. The new framework, and its predictive element, termed the "differentiating factor," is tested here in examining macro-economic crises, and subsequent changes in macro-economic policy, in America and Sweden.
\end{abstract}




\section{Introduction}

Institutionalists (for example, Christensen 1997; Gorges 2001; Mahoney 2000; Pierson 2000; Steinmo, 1989; Thelen and Steinmo 1992) have regularly argued that crises can result in abrupt institutional change. Often, crises are pointed to as the starting points in a sequence of change, as in path dependence. Consequently, scholars' interpretations of institutional change have resulted in the past's division into periods of normalcy, and critical junctures.

But, Pierson (2004: 5-6) argues that critical junctures, 'a concept needed in underpinning the analyses of temporal processes, have received only limited discussion.' Thelen (1999: 388) also points to the lack of sophisticated tools for understanding change. These arguments relate to the idea that historical institutionalism, in general, has tended to concentrate on the institutional, rather than the historic, side of the approach.

Of late, historical institutionalists have moved on from critical junctures, seeking new means to demonstrate how institutions are remade over time (Clemens and Cook, 1999; Pierson, 2004; Thelen, 1999, 2000). Consequently, the critical junctures concept, an only half developed approach as it is entirely postdictive, is being consigned to academic history. Simultaneously, with some scholars declaring events to be critical junctures, watersheds, or other turning point terms, without the provision of the least evidence, the concept is being rendered meaningless.

In the past critical junctures have been examined by means of unwieldy frameworks (Collier and Collier 1991), or counterfactual analysis (Fearon, 1991; 1996). Of late Hogan (2005; 2006) sought to develop a framework with greater rigour. But, this involved narrow, in many instances case specific, criteria, as well as arbitrary standards. Scholars have yet to develop a framework for examining critical 
junctures that is rigorous and widely applicable. All previous approaches have also lacked a predictive element. However, this paper seeks to develop a rigorous, widely applicable framework for examining critical junctures, which incorporates a predictive element.

Our hypothesis is: a critical juncture in macro-economic policy consists of three stages; macro-economic crisis, ideational change, and radical change in economic policy. The time periods concern rapid changes in macro-economic policy, as this is synonymous with the concept of critical junctures. Through the study of five potential macro-economic crises in two countries, the paper will develop a set of a priori criteria for examining potential critical junctures. The reason for so many cases is, as Hall (1993: 277) encourages, broad concepts deserve exploration in many contexts, and no single case can fully resolve such issues. The paper will show that although there were five potential macro-economic crises not all were actual crises; and not all of the actual crises resulted in critical junctures in macro-economic policy.

The paper will explain what differentiates a macro-economic crisis that results in a critical juncture in economic policy from one that does not. This differentiating factor constitutes the essential predictive element. Once identified, it will be possible in future to look at any country experiencing economic difficulties, test to see if these difficulties constitute a crisis, test for the differentiating factor's presence, and then declare if there will be a critical juncture in that country's macro-economic policy. This would remove the longstanding element of contingency associated with critical junctures by path dependence scholars (Mahoney, 2000: 513), and eliminate the necessity of having to wait decades to conclude if an event was a critical juncture. Whilst this approach focuses on macro-economic crisis, and its consequences for 
macro-economic policy, the framework could examine a range of crises and their impact on various policies.

The first section discusses the critical junctures literature, focusing upon the frameworks developed; the range of issues studied, and the concept's postdictive nature. The second section sets out the countries chosen for examination, and the timeframe of study. The third section sets out and tests criteria for identifying macroeconomic crisis, ideational change, and macro-economic policy change. The conclusion will highlight the findings and significance of the paper.

\section{Section 1: The Characteristics and Uses of the Critical Junctures Approach}

Critical junctures are seen as constituting the trigger events that set processes of institutional, or policy change, in motion. The literature sees critical junctures resulting in the adoption of an institutional arrangement from among alternatives (Mahoney, 2000: 512). Thereafter, the pathway established funnels units in a particular direction, with the consequence of increasing returns, and resultant irreversibilities (Mahoney, 2003: 53; Pierson and Skocpol, 2002: 9). However, Pierson (2004) argues that institutional stability can result from non-path dependent causes, implying that critical junctures should not be defined by the assumption that they initiate path dependent processes.

For some, the duration of a critical juncture may involve a brief period, while for others it can constitute an extended period of reorientation (Mahoney 2001). The analysis of critical junctures has been influential in comparative politics. Collier and Collier (1991) developed a framework for determining critical junctures in national development in Latin America. Their definition does not imply institutional innovation occurs in short episodes (Thelen, 2004: 215). For Mahoney (2001), 
analysing the nineteenth century liberalization of Central America, critical junctures took decades to come about, while their effects were sometimes of shorter duration. Hogan $(2005 ; 2006)$ questioned whether these periods could be called critical junctures, or were instances of incremental change, labelled by Streeck and Thelen (2005) as periods of conversion.

However, critical junctures have also been employed in research into short term change. Garrett and Lange (1995: 628) showed that electoral landslides create critical junctures by producing mandates for policy change. Casper and Taylor (1996) employed critical junctures in analysing when authoritarian regimes were vulnerable to liberalization. Examining the 1934 Reciprocal Trade Agreements Act, Haggard (1988: 91) argued that economic depression brought into question existing institutions, resulting in dramatic change. Karl (1997) used the concept in analysing the "petro-states" problematic development paths; Gal and Bargal (2002) used it to analyse occupational welfare in Israeli, while Vargas (2004) used it to examine the Chiapas conflict. Hogan $(2005 ; 2006)$ remoulded the framework to examine change in trade union influence over public policy.

Critical junctures are regarded as pointing to the importance of the past in explaining the present. They 'suggest the importance of formative moments for institutions and organisations' (Pierson, 1993: 602). Consequently, the above studies were postdictive. But, if focusing on the formative moments of institutions is critical, only being able to do so retrospectively constitutes a significant weakness for the concept, something this paper seeks to remedy. 


\section{Section 2: The Countries Selected for Examination}

America and Sweden were selected for examination based upon most similar and most different criteria. For most similar we chose the criteria of long-standing democracy, and advanced capitalist state. We utilised Lijphart's (1999) categories of majoritarian and consensual democracies as the 'most different' basis for selection, allowing us to control for varying institutional arrangements. Both countries' economies are very different, while their performances, and the policies governing them, have varied dramatically. Thus, their similarities ensure the contexts of analysis are analytically equivalent, to a significant degree,' while their difference place 'parallel processes of change in sharp relief' (Collier, 1997: 40). Here we examine potential crises from their economic performance between 1945 and 2000.

\section{Section 3.1 The Identification of Macro-economic Crisis}

'An important part of the literature on critical junctures views them from the perspective of crises, placing particular emphasis on the tensions leading up to the critical juncture' (Collier and Collier, 1991: 32). 'Traditionally, students of institutional change focused on the importance of crisis,' (Cortell and Peterson, 1999: 184). Exogenous shock is often cited as an explanation for policy change (Greener, 2001; Golob, 2003: 373). Here the crises being searched for are macro-economic in nature. 'Most scholars agree that severe recessions make significant structural changes possible because they render politics highly fluid' (Garrett, 1993: 522). Governments, political parties, and their economic policies, are openly exposed to the impact of economic fluctuations, being readily affected by them. A macro-economic crisis can call into question existing institutions, policies, or even state projects, consequently triggering change (Tilly, 1975). 
Macro-economic crises are rare events rendering definition and identification difficult (Yu et al., 2006: 439). Consequently, how do we identify a macro-economic crisis? This issue relates to the broader concept of how problems move onto the policy agenda in the first instance. Stone (1989: 299) argues that a situation does not become a problem until it is seen as amenable to control. But, if it is controllable it must be measurable, otherwise how would we know if we are controlling the situation? Thus, a macro-economic crisis must be quantifiable to some extent. Kaminsky et al., (1998) and Berg and Pattillo (1999) advocated the use of individual variables when quantifying currency crises, a concept equally applicable to macroeconomic crises. Pei and Adesnik (2000: 138-139) developed a broader range of criteria for identifying macro-economic crises: an annual inflation rate greater than 15 per cent, stagnant or negative annual gross domestic product (GDP) growth, and historians and other analysts' descriptions of significant deterioration in economic and financial circumstances. For Garuba (2006: 21), Kwon (2001: 105), and Solimano (2005: 76) a macro-economic crisis can be seen in general indicators and perceptions of growth, inflation, employment creation, poverty reduction, and their combined socio-psychological burden on society. However, unlike Yu et al. (2006), we are not seeking to forecast macro-economic crises, merely identify them.

As Pei and Adesnik (2000: 139) note, defining any macro-economic downturn as a crisis requires subjective and objective deliberations. Consequently, González (2005: 93) suggests the adoption of a multifaceted approach, as these are situations in which failure is identified and widely perceived (Hay 1999: 324). Agents must diagnose, and impose on others, their notion of a crisis before collective action to resolve uncertainty can take meaningful form (Blyth 2002: 9). This fits with Hay's (1999: 321) perception of crisis as the triumph of a simplifying ideology. 
Consequently, we develop a broad range of observable implications, which include, and build upon, the objective and subjective criteria of previous studies. These implications accept that a macro-economic crisis must constitute a severe economic low point.

\section{Macro-economic Crisis}

The first three observables, largely quantitative in nature, are derived from Pei and Adesnik (2000), and Solimano (2005). However, we employ a lower inflation threshold than Pei and Adesnik, as the developed states studied here are not as susceptible to severe inflationary fluctuations as their developing counterparts.

The latter observables are partly derived from Pei and Adesnik's (2000) recommendation to examine historians', and other analysts', descriptions of economic deterioration to determine if there is a crisis. However, they also draw upon the work of Garuba (2006), Kwon (2001), and Soliman (2005) whose measures for economic crisis are more qualitative, and contextual, than quantitative.

O1. If the main economic indicators reached decade-long lows, the economy may have been in crisis.

O2. If annual inflation is greater than 10 per cent, the economy may have been in crisis.

O3. If annual GDP growth is stagnant or negative, the economy may have been in crisis.

O4. If opinion polls find the public regarded the economy in crisis, the economy may have been in crisis. 
O5. If the national media regarded the economy in crisis, the economy may have been in crisis.

O6. If economic and political commentators regarded the economy in crisis, the economy may have been in crisis.

O7. If the central bank regarded the economy in crisis, the economy may have been in crisis.

O8. If both domestic and international organizations (Organisation for Economic Cooperation and Development (OECD)) monitoring economic performance regarded the economy in crisis, the economy may have been in crisis.

09. If elected representatives regarded the economy in crisis, the economy may have been in crisis.

010. If government pronouncements on the economy were consistent with a crisis management approach, the economy may have been in crisis.

As space permits only the briefest review of the material examined, we concentrate on the most likely macro-economic crises identified.

\section{The United States of America}

Here we examine three possible macro-economic crises.

According to the OECD (1962: 5) by the late 1950s America was suffering from relatively high unemployment, and a large deficit. Time stated that the economy was in recession. ${ }^{1}$ The rate of unemployment stood at 5.5 per cent, or 3.7 million. $^{2}$ For the Labor Department, anything above 3 million indicated economic weakness. ${ }^{3}$ Inflation was at 1.5 per cent in 1959 and 1.3 per cent in 1960, while GDP growth fell from 7.2 per cent to 2.4 per cent in 1960 (Mitchell, 1998). 'By 1960 economists argued that the economy was slumping dangerously' (Heath, 1975: 63). The 
Secretary of the Treasury admitted as much at an IMF meeting. ${ }^{4}$ Democratic presidential candidate Kennedy observed that in 1959 America experienced the lowest growth of any major industrialized country. 'You don't see a burgeoning economy,' agreed his Republican rival Nixon. ${ }^{6}$ However, these factors were not sufficient to constitute an economic crisis.

For the OECD (1982: 9) the Carter administration's final year was characterized by high interest rates, and rising unemployment. Compounding matters, the National Bureau of Economic Research declared the economy in recession. ${ }^{7}$ When the President invoked the Credit Control Act it resulted in reduced borrowing, and a steep decline in growth. ${ }^{8}$ By 1979 , inflation stood at 11.3 per cent, rising to 13.5 per cent in 1980 , while GDP growth struggled at 2.4 per cent in 1979 , before slumping to -0.3 per cent by 1980 (Mitchell, 1998). By the second half of 1980 the administration's responses to the recession smacked of crisis-management. Carter's Economic Renewal Programme to stimulate the economy was highly criticized. ${ }^{9}$ By November Fed Chairman Volcker admitted there was a recession. ${ }^{10}$ In restraining the growth of the money supply the Fed pushed interest rates to their highest levels in a century, reducing consumer borrowing, and sending spending into decline. ${ }^{11}$ 'Through the actions of the Reserve Board and the administration, the economy was inadvertently plunged into the kind of recession the White House had been trying to avoid' (Dark, 1999: 120).

By 1992 the economy was in serious trouble (Caple, 1991: 3). In December 1990 Fed Chairman Greenspan called the downturn "meaningful."12 The OECD (1993: 18-29) showed that the economy shrank 1.2 per cent in 1991, while the budget deficit reached $\$ 290$ billion in 1992, with federal debt surpassed \$4 trillion. Inflation ran at 2.9 per cent in 1991 and 1992, while GDP growth was -0.9 per cent in 1991, 
before rising to 2.7 per cent in 1992 (Mitchell, 1998). The Wall Street Journal warned that the deficit was out of control, ${ }^{13}$ leaving no room to stimulate the economy. ${ }^{14}$ The Gulf War, the Savings \& Loan bailout, defence-industry contraction, real estate depression, and soaring welfare payments, wreaked havoc with budgetbalancing efforts. ${ }^{15}$ Unemployment peaked at 7.8 per cent in mid-1992. President Bush admitted that his administration had botched the recession. ${ }^{16}$ This economic downturn became the longest recession since the Great Depression. ${ }^{17}$

\section{Sweden}

Here we examine two potential macro-economic crises.

The recession that began in the mid 1970s proved persistent. The OECD (1982: 49) described the economy in 1982 as in difficulty. Government's expenditures had grown, while revenues stagnated. The budget deficits were financed by international borrowing (Siven, 1984: 17), and as a consequence the debt to GNP ratio increased by over 250 per cent in six years. In 1981 inflation reached 12.1 per cent, while GDP growth fell to -0.6 per cent. ${ }^{18}$ Unemployment reached 3.1 per cent in 1982, its highest level since 1945, a political scandal in a country accustomed to full employment. ${ }^{19}$ However, economists believed unemployment would have been closer to 16 per cent if it included the jobless in training programmes, workers forced into early retirement, and those who had given up looking for work. ${ }^{20}$ The New York Times argued that the Swedish economy had been hobbled by foreign debt, low investment, and an adverse balance of payments. ${ }^{21}$ The economy was in crisis.

Although prosperity returned during the 1980s, by the 1990s, Sweden was suffering further economic malaise. Attempts to maintain industrial competitiveness, an enormous public sector, and full employment, resulted in spiralling inflation. ${ }^{22}$ 
The Bank of International Settlement observed that Sweden's 10.5 per cent inflation rate was the worst of the ten leading industrialised countries. ${ }^{23}$ In 1990 prices rose by 6.6 per cent, against the OECD (1992: 12) average of 4.5 per cent. GDP contracted by 1.1 per cent in 1991, and 1.4 per cent in 1992 (Mitchell, 1993). That autumn the real estate market collapsed, putting the banking system in jeopardy, ${ }^{24}$ and threatening the country's financial infrastructure (Martin, 2000: 246). Unemployment increased from 1.7 per cent in $1990^{25}$ to 5.3 per cent in 1992 . The current budget deficit, public sector borrowing requirement, and national debt, all rose as the economy contracted. ${ }^{26}$ The Guardian stated that 'this was the first time the [Swedish] economy contracted since 1942., 27 "Sweden is in a very severe recession. There is crisis in every part of the public sector," said Anders Aslund, Sweden's leading economist. ${ }^{28}$

Insert Table 1 about here

Of the five potential macro-economic crises, four constituted authentic crises, satisfying all, or nearly all, of the observable implications. As can be seen in Table 1, America 1959-1961 satisfied only one observable implication, and thus could not be a severe economic low point. The next section will examine the four macro-economic crises to see if ideational change occurred at these times, and, central to our hypothesis, if policy change followed ideational change.

\section{Section 3.2 Identification of Ideational and Policy Change}

A crisis presents new problems, as previous policies are discredited due to their implication in, or inability to right, the situation (Levy, 1994). Economic crises can have great impact, shaping a range of alternatives, but they will not determine policy 
choices. These remain 'firmly centred in domestic political and ideational processes' (Golob, 2003: 375). Ideas are crucial in determining policy choices due to uncertainty over the basic workings of the macro-economy, the difficulties of interpreting policy effectiveness, and the lack of agreement over what constitutes "correct" macroeconomic policy (McNamara, 1998: 57). When an economic model is in flux, windows of opportunity (Kingdon, 1995) will appear in which change agents will contest the viability of the prevailing paradigm. They will present a range of new ideas to replace the ones upon which existing policy is based. Thus, ideas influence policy by acting though particular actors (Berman, 1998: 22). Consequently, we contend that significant policy change is dependent upon change agents reaching a broad consensus upon, and subsequently consolidating around, one particular set of new ideas. These ideas will determine the path of subsequent policy, as policy makers work within a framework of ideas and standards that specify not only the goals of policy, but the instruments to be used to achieve these goals, and the very nature of the problems they are meant to be addressing (Hall, 1993: 279).

The period of flux outlined above is similar to Blyth's 'discursive phase,' where 'agents interested in reforming existing distributional arrangements contest the definition, meaning and solution to the problems identified by opposing economic ideologies' (1997: 234). It is also analogous to what Oliver and Pemberton (2004: 419) describe as the 'institutional battle.' 'Economic ideas facilitate the reduction of...barriers by acting as coalition-building resources among agents who attempt to resolve the crisis' (Blyth, 2002: 37). Thus, ideas are the casual mechanisms of change in any critical juncture (Golob, 2003).

Once agents coalesce around a set ideas, which purport to offer a solution to current economic woes, and an alternative to the current paradigm, they will attempt 
to 'inject' these into the policy domain. We contend that there are three groupings of change agents. The most important agents are what Dahl (1961) termed 'political entrepreneurs.' Political entrepreneurs, according to Sheingate (2003: 188-190), 'exploit moments of instability' and 'invest resources in the creation of a new policy, a new agency, or new forms of collective action.' They are similar to Kingdon's (1995) broader concept of policy entrepreneurs, which constitute our second group of change agents. Policy entrepreneurs encompass civil servants, technocrats, academics, economists and interest groups etc., who engage in policy innovation, and have access to decision makers. However, Sheingate (2003) highlights the role of political leaders as political entrepreneurs: in times of crisis, 'uncertainty makes possible the speculative, entrepreneurial quality of everyday politics...as politicians engage in a steady search for political advantage' (2003: 192). Thus, in a crisis, a political leader, usually an opposition leader, will introduce new economic policy ideas to rectify the ills of the existing paradigm. Policy entrepreneurs are generally responsible for producing the ideas, but it is the political entrepreneur who acts as a figurehead, introducing these ideas into the policy process. As Margaret Thatcher quipped to Ralph Harris of the Institute of Economic Affairs (IEA), when he claimed the IEA had been advocating market reform twenty years before her time, 'Ralph, the cock may crow but it's the hen that lays the egg. ${ }^{29}$ The triumph of a new idea depends upon 'a workable new idea being available' which change agents are prepared to adopt, and promote (Oliver and Pemberton, 2004: 419). The final group of change agents are outside influences, encompassing the media, and international organizations, such as the OECD. They will critique an existing economic paradigm, advocating a new set of economic ideas as an alternative. These three broad groupings are similar to those identified by Pemberton in his schema of policy 
learning (2000: 777). He notes that while minor policy changes emanate from administrators, significant changes are dominated by academics, economists, interest groups, the media, and in particular politicians.

Greener (2001: 134) sees an important role for exogenous shocks in securing the triumph of a new policy paradigm. However, we hypothesize that a macroeconomic crisis is a necessary, but insufficient, condition for change in macroeconomic policy. Instead, a macro-economic crisis will result in debate regarding the economy, and the generation of new ideas. The consolidation of agents around a set of new ideas is crucial for policy change. This corresponds to McNamara's (1998: 45) argument that actors utilize new ideas to chart new policy strategy. Consequently, the following observable implications seek to identify the generation of new economic ideas by agents.

\section{Ideational Change}

01. A clear change agent (political entrepreneur) to inject new ideas into the policy arena is evident.

O2. Opposition political parties critique the current model and propose alternative economic ideas - at election time their platform will be built around these alternative ideas.

O3. Civil society organizations, e.g. labour unions, employer organizations, consumer groups etc. critique the current model, reflecting Hall's (1989: 12) coalition-centred approach.

O4. A clear set of alternative economic ideas, as developed by policy entrepreneurs, are evident. 
O5. Widespread public dissatisfaction with the current paradigm, observable through opinion polls, protests etc.

O6. External or international organizations critique the current model and/or actively disseminate alternative economic ideas to replace this model.

07. The media questions the efficacy of the current economic model and/or specific policy areas.

Should a broad range of agents agree that the prevailing paradigm is inadequate, and should be replaced, the first stage of Legro's (2000: 419) model of rapid ideational change, collapse, will have occurred. However, 'even when ideational collapse occurs, failure to reach consensus on a replacement could still produce continuity, as society reflexively re-embraces the old orthodoxy' (Legro 2000: 424). Walsh (2006: 494) sees this as the continued implementation of failed policies due to a lack of coherent intellectual links between policy tools and desired outcomes.

Thus, in the wake of ideational collapse, the issue is reaching consensus on a new set of ideas. If consensus is achieved it constitutes the second stage of Legro's model - consolidation - agents co-ordinating a replacement set of ideas to the reigning consensus. This can be seen in political entrepreneurs consolidating their innovations' by combining a mixture of interests to produce a winning coalition (Sheingate 2003: 192-193).

Extant ideas constitute the "armour" protecting policies. The greater the level of consensus encompassing an idea the heavier the armour protecting the policies derived from it. Armoured policies represent continuity, whereby once a policy has become institutionally embedded, 'policy-making becomes possible only in terms of 
these ideas' (Blyth, 2001: 4). Referring to policies as armoured is similar to Golob's notion of 'policy frontiers' (2003: 363).

However, with the replacement of old ideas the policies based upon them will have lost their armour protection. Pemberton (2000: 790) argues that new ideas change the wider policy environment. Thus, we hypothesize that once there is consolidation around a new set of ideas, a significant change in policy should follow. In this regard ideational change will constitute the "differentiating factor" between crises that result in radical policy change, and those that do not. Therefore, we must discover if radical changes in economic policy follows ideational change. Thus, we have opted to base our final set of observable implications upon the concepts of first, second, and third order changes in policy developed by Hall (1993). Hall (1993: 291) argued that policy failures and exogenous shocks can set off processes that lead to ideational change, to the extent of resulting in the re-examination of the belief systems through which policy has been generated - a paradigmatic (third order) policy change. These observables will enable us identify, and differentiate, both normal and fundamental shifts in a country's macro-economic policies. However, the observables set out here also incorporate the ideas of swift and enduring change developed by Hogan (2005). As we are dealing with the idea of radical change we assume that this is not a long process, otherwise it would constitute incremental change. Also, if the change is to be enduring in a policy environment full of competing actors, policy entrepreneurs, and policies in search of a home, it should survive for at least one change of government. Otherwise, the new policies will have proven themselves lacking armoured protection (i.e. institutional embedding) necessary to see them endure. As we are searching for the paradigm shift in macro-economic policy this must encompass all three of the below observables. 


\section{Policy Change}

01. If economic policy instrument settings changed (swiftly; for longer than one government's term of office) there may have been a radical change in government economic policy.

02. If the instruments of economic policy changed (swiftly; for longer than one government's term of office) there may have been a radical change in government economic policy.

03. If the hierarchy of goals behind economic policy changed (swiftly; for longer than one government's term of office) there may have been a radical change in government economic policy.

\section{America 1979-1981}

By the end of Carter's administration the US economy was in trouble. Paul Volcker, Federal Reserve Chairman, believed the remedy for spiralling inflation was a tightened money supply (Krugman, 1990), the first coherent move towards monetarist policy. However, the results were limited. The president's imposition of new controls on consumer credit contributed to the economy's slide. Consequently, there was widespread dissatisfaction with, and critiques of, government policy.

Time argued that Carter's decisions resulted in reductions in consumer borrowing, and a steep decline in growth. ${ }^{30}$ 'Recession Hits Hard' headlined The Washington Post. ${ }^{31}$ Economic commentators were pessimistic on the prospects for recovery. The economy was in what Walter Okun called the great stagflation swamp. ${ }^{32}$ The President's inflation record is not good admitted Walter Heller. In allowing the economy deteriorate, noted Alan Greenspan, Carter was forced into a crash programme of restraint leading to a huge rise in unemployment. ${ }^{33}$ The critiques 
began to coalesce around a set of alternative economic ideas purporting to tackle current economic ills: monetarism. With agents in agreement on the inadequacy of the extant paradigm, ideational collapse had occurred.

Monetarist concepts had been present in American political circles since the early 1970s, with Milton Friedman, Robert Lucas, and Arthur Laffer, founding organizations such as the American Enterprise Institute (Blyth, 1997: 236-237). These groups ensured that by the late 1970s American economic journalism propagated their ideas (Blyth, 1997: 237), with the Wall Street Journal acting as both 'effective synthesizer and chief proselytizer for these...ideas' (Blyth, 2002: 164). In this respect both a clear set of alternative ideas and policy entrepreneurs were present.

However, it was Ronald Regan, the Republican candidate for President, who embraced this new ideology, and adopted the role of political entrepreneur. His message was lower taxes, reduced spending on social services, balanced budgets, and fewer governmental regulations. He blamed the Democrats' inflationary policies for stifling productivity, and bringing recession. In late August, Reagan stated that President Carter had 'created a severe depression. ${ }^{34}$ He promised new policies and leadership (Wayne, 1992: 182). During the final stages of the election Reagan declared Carter's record on inflation and unemployment 'a failure on a scale so vast, in dimensions so broad, with effects so devastating, that it is virtually without parallel. $^{35}$ Regan forged an electoral coalition around the notion of monetarism (Blyth, 1997), and won the election on the back of having a discernable set of alternative economic ideas which could replace existing arrangements. For the OECD (1982: 10) President Reagan's election, and the accompanying Congressional election, was a clear mandate for conservative policies. Consequently, in the wake of an economic crisis, and with the paradigm underlying extant economic policy 
collapsed, change agents reached consensus, and consolidated around, a new economic orthodoxy. Monetarism's wide acceptance as a viable alternative idea constituted ideational change. Thus, with the ideas fundamental to existing policy replaced, those policies were no longer armoured, and were easily changed.

The new administration's economic policies were very different from those of its predecessors in their political roots, and theoretical foundations (OECD, 1982: 9). Reagan fashioned his economic strategy around the monetarist proposals of Arthur Laffer. To combat stagflation he promoted a painless panacea: tax cuts, and deregulation, wherein the resulting stimulus would boost federal revenues to balance the budget, reducing inflationary pressure. The new President's programme, dubbed Reaganomics, constituted the belief that American capitalism, freed from the burden of taxes and regulation, would surge ahead. Reagan's first budget proposed a $\$ 750$ billion tax cut over three years (Jones, 1995: 597). The administration also cut $\$ 11$ billion from public works and job training programmes, unemployment benefits programmes, and trade adjustment assistance-benefits. ${ }^{36}$ According to the OECD (1982: 24) 'a trend towards reduced economic regulation was carried further by the immediate application of the remaining stages of crude oil price decontrol, and the abolition of the Council on Wage and Price Stability.'

In political terms Reagan capitalised on anti-government sentiment, emphasising individualism, and a smaller Federal role. Tax relief was allied to a restructuring of federal expenditure, bringing sharp changes in the fiscal influence on the economy. Economic policy instrument settings, the instruments themselves, and the goals behind economic policy, all changed. This third order change (paradigm shift) in macro-economic policy endured into the administration of Reagan's 
successor. D’Souza (1997: 85) argues that Reagan's programme for America was the most ambitious since the New Deal.

An economic crisis led to the collapse of the ideas underlying existing macroeconomic policy. Policy and political entrepreneurs advocated a replacement set of ideas, namely monetarism. Consolidation around this new economic orthodoxy was achieved with the coming of Roland Reagan. Following his election there was a third order change (paradigm shift) in macro-economic policy. Thus, we have a macroeconomic crisis, ideational change, and a radical change in macro-economic policy, which according to our overarching hypothesis constituting a critical juncture in macro-economic policy.

\section{America 1990-1992}

The Bush administration was blamed for the recession of the early 1990s. The Gulf War, along with a range of domestic economic problems left a legacy of disastrous budget deficits. ${ }^{37}$ With national debt exceeding $\$ 4$ trillion, and huge interest repayments, artificially stimulating the economy was not an option. ${ }^{38}$

The public lost faith in the administration's ability to manage the economy. An August 1992 poll by Time showed only 22 per cent of the public regarded President Bush as performing a good job. ${ }^{39}$ A Newsweek poll the following month produced similar results. ${ }^{40}$ Time argued that the Reagan/Bush administrations were largely responsible for the red ink on the federal budget. The New York Times stated that from the start Bush had mismanaged the economy. ${ }^{41}$ However, when new taxes were levied, vicious criticism ensued. 'Read My Lips: I Lied' proclaimed a New York Post headline. ${ }^{42}$ 'Anxious about the economic future?' asked Newsweek, 'if you aren't you should be,' it warned. ${ }^{43}$ Even the World Bank attacked Bush's economic 
management. 'The most important lesson of elementary economics America must learn,' said World Bank chief executive Laurence Summers, 'is: deficit finance is not an alternate to cutting spending or raising taxes. ${ }^{44}$ Confidence in extant economic ideas had collapsed.

The 1992 Democrat Presidential nominee, Bill Clinton, attacked the administration for the economy's ills. Clinton pledged an activist government addressing the economy, jobs, and health care. His campaign focused on the recession, with the famous maxim: 'The Economy Stupid!" 45 Although critiques of Bush's administration were rife, unlike the previous example, these debates did not coalesce around an alternative set of economic ideas. Clinton merely repackaged the existing economic ideas. Consequently, there were no alternative ideas for agents to consolidate around. The result was continuity with the old economic orthodoxy. Clinton was elected on the back of Bush's unpopularity, with economic proposals aimed at rectifying Bush's errors, rather than changing economic policy. The ideas he espoused did not constitute an alternative economic paradigm, nor were any significant change agents present. Consequently, Clinton came to power without any radically new economic ideas to inject into the policy arena.

Nevertheless, he was determined to revive the economy. Consequently, there was some change in the government's economic policies. Clinton (1992: 46) argued for a new economic programme putting people back to work. Seeking to shed the Democratic Party's reputation for ultra-liberalism, and wasteful spending, he sought to court the middle class, and blue-collar voters, who had once composed the party's backbone. But, in so doing he would fail to bring about a third order change (paradigm shift) in macro-economic policy. 
The recession shaped much of Clinton's agenda. The OECD (1993: 14) argued that his administration's economic strategy was built on the view that government could improve market outcomes, and had greater scope for correcting market failures. 'The zeal for deregulation has waned since the mid-1980s, and the government seems willing to turn to new regulation to achieve its social objectives in an environment of budgetary stringency' (OECD, 1993: 117).

Rejecting the 'trickle down' approach of the Reagan-Bush years, Clinton proposed the government revitalize the economy through investment in infrastructure and education (French, 1997: 52). His 1993 economic programme proposed spending cuts and tax increases with a deficit reduction of $\$ 325$ billion over four years. One of the programmes main components was a $\$ 169$ billion stimulus package. In August, Congress passed a five-year economic plan incorporating Clinton's spending cuts and tax increases, while gutting his stimulus package. Nevertheless, the OECD (1993: 113) argued that this deficit-reduction plan alleviated the fiscal imbalances.

While the administration was committed to bringing down the deficit, to ease the drain on national savings, it also showed a willingness to counter rising income inequality, secure faster job creation, and support higher rates of investment in all forms. Although economic policy instrument settings, and the instruments themselves, may have changed, the hierarchy of goals behind economic policy did not. This constituted a second order change in macro-economic policy.

The economic crisis witnessed the collapse of extant economic orthodoxy. However, change agents did not consolidate around a clear set of alternative economic ideas. Consequently, the ideas underpinning the economic policies of the Regan/Bush years endured, providing them with a level of armoured protection 
sufficient to deflect unconsolidated ideational attack. There was no critical juncture in economic policy.

\section{Sweden 1980-1982}

The recession of the 1970s saw the budget deficits supporting the social welfare system deepen. By 1981 the non-socialist coalition government held only 102 of the 350 seats in the Riksdag. ${ }^{46}$ In autumn 1981 the krona was devalued by 10 per cent, and the following spring the government introduced far-reaching austerity measures. However, the opposition parties gained ground (Hadenius, 1997: 129-130). The government hoped its attempts to combat the economy's problems would generate respect for non-socialist policies, instead they generated widespread critiques, and initiated a debate on the economy. The Financial Times pointed out that the Swedes were nervous about the future, but reluctant to see the welfare state's benefits reduced. ${ }^{47}$ "The welfare state is in a crisis of legitimacy,' observed Hans Vetterberg, Sweden's leading public opinion analyst. 'We can no longer afford to keep expanding it."48 Not surprisingly, the Swedish Employers' Federation (SAF) was unhappy with the government. However, the non-socialist government wanted neither to raise taxes, nor dismantle the welfare state. ${ }^{49}$ This situation, rife with unfulfilled economic expectations, and agents dissatisfied with the prevailing paradigm, constituted ideational collapse.

The 1982 election was deemed crucial as it would determine whether public perception had shifted, as in Norway and Denmark, away from the Social Democrats. The election campaign was dominated by talk of economic crisis - a $\$ 10$ billion debt to foreign banks, inflation, declining exports, and increasing unemployment. ${ }^{50}$ During the campaign the Social Democrats attacked the viability of another non-socialist 
government, and their economic policies. The party presented a program on how Sweden could save and work its way out of crisis. Ultimately, the election, and the debates surrounding it, failed to generate either a coherent set of alternative economic ideas to replace the existing ones, or a significant agent of change. The non-socialist parties failed to create a coalition around ideas alternative to the welfare state, and nearly all economic ideas presented were variations on existing themes. So, despite the failure of the dominant orthodoxy, change agents failed to reach consensus on a replacement set of ideas. With failure to consolidate around a new ideational orthodoxy agents reflexively re-embraced the old. In lieu of alternatives, the ideas underpinning the policies of the welfare state endured. Consequently, the SAP won the election, not on the back of a new economic paradigm that could cure the country's economic woes, but on a series of proposals to rectify existing economic arrangements.

The result precipitated an altered approach to economic management, with minor changes in economic policies. The SAP, admitting there were no ready solutions to the economy's problems, ${ }^{51}$ implemented a recovery programme - The Third Road. This approach argued that renewed growth required redistribution of income from labour to capital. It constituted a shift in SAP economic planning, behind which course lay the influence of its research unit, as opposed to those of the unions. This marked an attempt to maintain a level of social democracy, which other countries were rolling back (Martin, 2000: 234). The Third Road sought to devise a wide-ranging stabilization programme encompassing demand management measures, as well as initiatives to promote structural change and ensure an equitable distribution of the burden of adjustment (OECD, 1984: 21). The SAP was also determined to pour funds into job creating industries. ${ }^{52}$ 
The centrepiece of finance minister Feldt's strategy to boost corporate profits was devaluation of the krona. This measure was implemented in conjunction with a price freeze, and increases in sales and corporate taxes, in a sweeping "crisis plan",53 aimed at stimulating the economy. ${ }^{54}$ According to the OECD (1984: 21) the objective was to achieve export led, investment driven, recovery. The Landsorganisationen $i$ Sverige (LO) accommodated devaluation by demanding average wage increases of 2.5 per cent in the ensuing wage-bargaining round. The devaluation and international economic recovery resulted in high earnings and excellent scope for export expansion (Ahlén, 1989: 333). The government also restored welfare entitlements cut by the non-socialists (OECD, 1984: 23).

To maintain the welfare state by whatever means necessary the government prioritized private sector growth, profits, and market forces. In this case, the economic policy instrument settings changed, but the instruments of economic policy, and the goals behind economic policy, remained much the same - the maintenance of the welfare state. This constituted a first order policy change.

The economic crisis in Sweden generated significant debate, and a form of ideational collapse occurred. However, change agents did not consolidate around a replacement economic orthodoxy. As a result, the extant economic paradigm endured, providing the existing economic policies with sufficient armoured protection to remain largely intact. There was no critical juncture in economic policy.

\section{Sweden 1990-1992}

Sweden's economic crisis in the early 1990s provided a window of opportunity for monetarist ideas to gain salience. Following the SAP's election in 1982, a number of agents began coalescing around alternative economic ideas, specifically monetarism. 
The SAF created, Centre for Business and Policy Studies (SNS), and Timbro, disseminated monetarist ideas, which gained ground, especially among influential economists such as Assar Lindbeck (Blyth 2002: 214-15). Political and policy entrepreneurs, consisting of the leaderships of the Conservative and Liberal parties, the policy elites outside the original social bargain, the SNS and SAF, began aggressively propagating these ideas (Blyth, 1997: 239).

Meanwhile, the media continued to harangue the SAP government, and its policy failures. The New York Times stated that the economy was stagnant. ${ }^{55}$ The Financial Times pointed out that in 1991, under the impact of weak foreign demand, and losses in competitiveness, Swedish exporters lost ground internationally. ${ }^{56}$ The Washington Post argued that Swedes were troubled by the country's slow growth, and doubts about their ability to maintain the standard of living to which they were accustomed. ${ }^{57}$

Once the economy entered freefall, critiques of the SAP by the media, the opposition, and the OECD, enabled change agents to propose monetarism as an alternative economic paradigm. In an environment of unfulfilled collective economic expectations, contestation of the existing economic orthodoxy by agents, agreed on both its inadequacy and need for replacement, resulted in its collapse. From the mid1980s onwards the SAF, among others, had increasingly called into question the corporatist system (de Geer, 1992: 155-157). The SAF took on the role of a vigorous policy entrepreneur, mounting intense publicity campaigns to improve the electoral prospects of the Liberal and Conservative parties. The SAF's ideas on privatization, and deregulation, also influenced the SAP government. To combat the crisis, the SAP, prior to the 1991 election, began incorporating monetarist ideas into policy. In 1990 currency outflows prompted the Riksbank to increase interest rates. ${ }^{58}$ To reduce 
inflation, the government tightened fiscal policy (OECD, 1992: 11), a significant change in macro-economic policy for an SAP government that previously attached top priority to the maintenance of high employment. As the economy depended on tight fiscal and monetary policies this meant giving highest priority to keeping inflation at the European level, even at the cost of unemployment, something previously unacceptable. ${ }^{59}$ The January 1991 budget highlighted the consolidation of monetarist ideas, as low inflation became the objective of economic policy (OECD, 1992: 39).

The internationalization of financial markets restricted the ability of the government to pursue economic policies diverging from those of other capitalist states, forming a 'cognitive lock' (Blyth, 2002). Policies disapproved of by industrialists (and foreign currency dealers) became increasingly difficult to implement (Marshall, 1996: 9).

The 1991 election saw the opposition parties reach consensus around monetarist ideas, a coherent set of alternative economic theories to rectify the economy. Following the election, Carl Bildt, leader of the Moderate Party, formed a four-party government advocating a switch to monetarism. The Financial Times observed that 'Swedish politics have reached the end of the Social Democratic era. ${ }^{60}$ Bildt summed up the result as "a massive mandate for change." 61 Thus, following an economic crisis a range of agents consolidated around a new set of economic ideas to replace those that had collapsed. As the orthodoxy underpinning existing policies was replaced, these polices lost the ideational armour that had protected them from change. Sweden had accepted the idea of an alternative economic paradigm.

The coalition government sought to fundamentally change the economy's structure. To right the economy it slashed the role of the state, ${ }^{62}$ selling its shares in 
34 companies, ${ }^{63}$ with a value of SKr250 billion. ${ }^{64}$ In limiting how far state responsibility should extend, Carl Bidlt challenged the conventional wisdom since the 1930s. ${ }^{65}$ According to the OECD (1992: 44) a central element of the new economic programme was reduced taxes, matched to reduced spending, to encourage efficiency. Competitive forces were given a greater role in allocating resources in the economy (OECD, 1992: 40). The new administration reduced the benefit system, and began abolishing the employee investment funds, ${ }^{66}$ using their resources to support the development of companies (Hadenius, 1997: 153). This change reflected concerns that past policies, especially the expansion of the public sector, involved high costs in lost economic dynamism, and had undermined Sweden's growth prospects. In seeking to change Sweden from social democracy to a more free market economy this government achieved more in its first six weeks in office than any pervious nonsocialist administration. ${ }^{67}$

An economic crisis led to the collapse of the dominant economic orthodoxy. The SAF, acting as a policy entrepreneur, introduced alternative monetarist economic ideas, around which consensus developed, leading to their consolidation. Following the SAP's electoral defeat advocates of monetarism set about changing the setting, instruments, and hierarchy of goals behind economic policy, constituting a third order change (paradigm shift) in macro-economic policy. This change in macro-economic policy, proceeded by both macro-economic crisis, and ideational change, constituted a critical juncture.

Insert Table 2 about here

Insert Table 3 about here 
Of the four macro-economic crises examined, two (America 1979-1981; Sweden 1990-1992) witnessed third order changes (paradigm shifts) in macro-economic policy. We can see from the case studies that these third order policy changes occurred following the collapse of the dominant economic orthodoxies, the introduction of new ideas into the policy arenas, and the subsequent consolidation of change agents around these ideas. The other two macro-economic crises (Sweden 1980-1982; America 1990-1992) did not witness third order changes in macroeconomic policy. Although ideational collapse occurred in both cases, change agents did not consolidate around replacement economic orthodoxies. Consequently, the hierarchy of goals behind existing macro-economic policy did not change.

These findings validate our hypothesis. Namely, a critical juncture in macroeconomic policy consists of three stages: macro-economic crisis, ideational change, and radical policy change. The findings show that a macro-economic crisis is a necessary, but not sufficient, condition for there to be a paradigm shift in macroeconomic policy. A macro-economic crisis not followed by ideational change, will at most, lead to a first or second order macro-economic policy change (Sweden 19801982; America 1990-1992). Whereas, a macro-economic crisis followed by ideational change (collapse and consolidation) will witness a third order change (paradigm shift) in macro-economic policy (America 1979-1981; Sweden 19901992).

Thus, when examining the degree of macro-economic policy change in the wake of a macro-economic crisis, ideas occupy a central, and yet dichotomous, position. The extant ideational orthodoxy provides the armour protecting existing macro-economic policy, ensuring its continuity. However, should ideational collapse occur, then the existing macro-economic policy is no longer armoured. If change 
agents manage to subsequently consolidate around a new set of economic ideas the result will be ideational change, and a third order change in macro-economic policy. However, if these agents fail to consolidate around a new economic orthodoxy, extant ideas will endure, ensuring a first, or second, order policy change at most. Therefore, ideational change clearly constitutes the "differentiating factor" between an economic crisis that leads to a paradigm shift in macro-economic policy, and one that does not.

\section{Conclusion}

As political science is continuously seeking better tools with which to make sense of change, any new, or revised, instrument should be eagerly welcomed. This paper sought to develop an improved framework, incorporating an a priori element, for examining critical junctures. We hypothesised that a critical juncture in macroeconomic policy consisted of: macro-economic crisis, ideational change, and radical policy change. Of the case studies examined America 1979-1981 and Sweden 19901992 fulfilled all three stages. In both cases the ideational foundations of existing macro-economic policy collapsed in the wake of economic crises, and were replaced as change agents consolidated around new economic orthodoxies. Third order macroeconomic policy change, paradigm shift, followed ideational change. America 19591961 was merely an economic downturn, but Sweden 1980-1982, and America 19901992, both constituted economic crises. While ideational collapse occurred in both cases, change agents did not consolidate around viable alternative ideas, and in the absence of ideational change, there was only minor macro-economic policy change.

We conclude that during a macro-economic crisis, ideational change is the key component leading to third order change in macro-economic policy. Established policies, and the armoured protection afforded by their underpinning ideas, having 
been brought into question by previous failures, are liable to be overcome by change agents consolidating around new ideas (America 1979-1981; Sweden 1990-1992). In the absence of ideational change the level of policy change, in response to a macroeconomic crisis, will be either of the first or second order, but not the third. Thus, economic policy instrument settings, and the instruments themselves may change, but without ideational change the hierarchy of goals underpinning macro-economic policy will remain unaltered (Sweden 1980-1982; America 1990-1992). Ideational change constitutes the "differentiating factor" between those macro-economic crises that are followed by a third order change (paradigm shift) in macro-economic policy, and those that are not. Following a macro-economic crisis the presence, or absence, of ideational change should enable us predict if there will be a third order change in macro-economic policy, and consequently a critical juncture.

This paper draws upon crisis, ideational, and institutional literature, to forge a rigorous framework capable not only of analysing macro-economic policy change, but other policy change also. The framework, with some minor modification, could be utilised to predict policy outcomes in such divergent fields as foreign policy, democratization, gender mainstreaming, as well as social and/or environmental policy. By testing the framework in these policy areas, it should either validate and improve the framework, or falsify it. By incorporating a predictive element - the differentiating factor - into the concept of critical junctures the framework breaks new ground. Thus researchers, having identified a crisis (of whatever kind), and ideational change, should be able to predict that a third order policy change, a paradigm shift, is coming, or if it has taken place, that the event constitutes a critical juncture. Researchers will no longer have to wait years to be able to declare an event a critical 
juncture. The predictive element broadens the applicability of the concept, deepens its incisiveness, and contributes to a better understanding of policy change.

\section{Endnotes}

${ }^{1}$ Time International, 13 July 1959, Vol. 74, No. 2, p. 14.

2 ibid., 3 October, 1960, Vol. 76, No. 14, p. 58.

${ }^{3}$ Newsweek, 5 September, 1960, Vol. 56, No. 10, p. 48.

${ }^{4}$ The Economist, 1 October, 1960, Vol. 197, No. 6110, p. 42.

${ }^{5}$ Time International, 19 September 1960, Vol. 76 No. 12, p. 19.

6 ibid., 22 August, 1960, Vol., 76, No. 8., p. 13.

7 ibid., 16 June, 1980, Vol. 115, No. 24, p. 48.

${ }^{8}$ ibid., 28 July, 1980, Vol. 116, No. 4, p. 44

${ }^{9}$ The New York Times, 2 September 1980, p. 12.

${ }^{10}$ The Washington Post, 20 November 1980, p. B1.

${ }^{11}$ Time International, 16 June, 1980, Vol. 115, No. 24, p. 50.

12 ibid., 31 December, 1990, p. 50.

${ }^{13}$ The Wall Street Journal. 18 September 1992, p. F1.

${ }^{14}$ Time International, 28 September, 1992, Vol. 140, No. 39, p. 32.

15 ibid., 28 September, 1992, Vol. 140, No. 39, p. 31.

16 ibid., 26 October, 1992, Vol. 140, No. 43, p. 28.

17 ibid., 28 September, 1992, Vol. 140, No. 39, p. 31.

${ }^{18}$ The Economist, 28 August, 1982, p. 41.

${ }^{19}$ The New York Times, 20 September, p. 3.

${ }^{20}$ Time International, 20 September, 1982, Vol. 120, No. 38, p. 32.

${ }^{21}$ The New York Times, 20 September, p. 3.

${ }^{22}$ The Economist, 21 September, 1991, p. 33.

${ }^{23}$ The Times, 11 June, 1991, p. 4.

${ }^{24}$ Financial Times, 23 October, 1991, p. v.

${ }^{25}$ Time International, 30 September 1991, Vol. 138, No. 14, p. 21.

${ }^{26}$ The Economist, 7 September, 1991, p. 38.

${ }^{27}$ The Guardian, 13 September, 1991, p. 5.

${ }^{28}$ Christian Science Monitor, 22 October, 1991, p. 3.

${ }^{29}$ Financial Times, 20 October, 2006, p.15.

${ }^{30}$ Time International, 28 July, 1980, Vol. 116, No. 4, p. 44

${ }^{31}$ The Washington Post, Business and Finance, 31 August, p. L1.

32 Time International, 29 September, 1980, Vol. 116, No. 13, p. 17.

${ }^{33}$ ibid., 29 September, 1980, Vol. 116, No. 13, p. 45.

34 ibid., 28 August, 1980, p. 9.

${ }^{35}$ Time International, 3 November, 1980, Vol. 116, No. 18, p. 17.

${ }^{36}$ The Washington Post, 16 February, 1981, p. A1.

${ }^{37}$ ibid., 28 September, 1992, Vol. 140, No. 39, p. 31.

38 ibid., 28 September, 1992, Vol. 140, No. 39, p. 32.

${ }^{39}$ ibid., 31 August, 1992, Vol. 140, No. 9, p. 29.

${ }^{40}$ Newsweek, 21 September 1992, p. 40.

${ }^{41}$ The New York Times, 21 October, 1992, p. 2.

${ }^{42}$ New York Post, 24 June, 1990, p. 1.

${ }^{43}$ Newsweek, 26 October 1992, p. 44. 


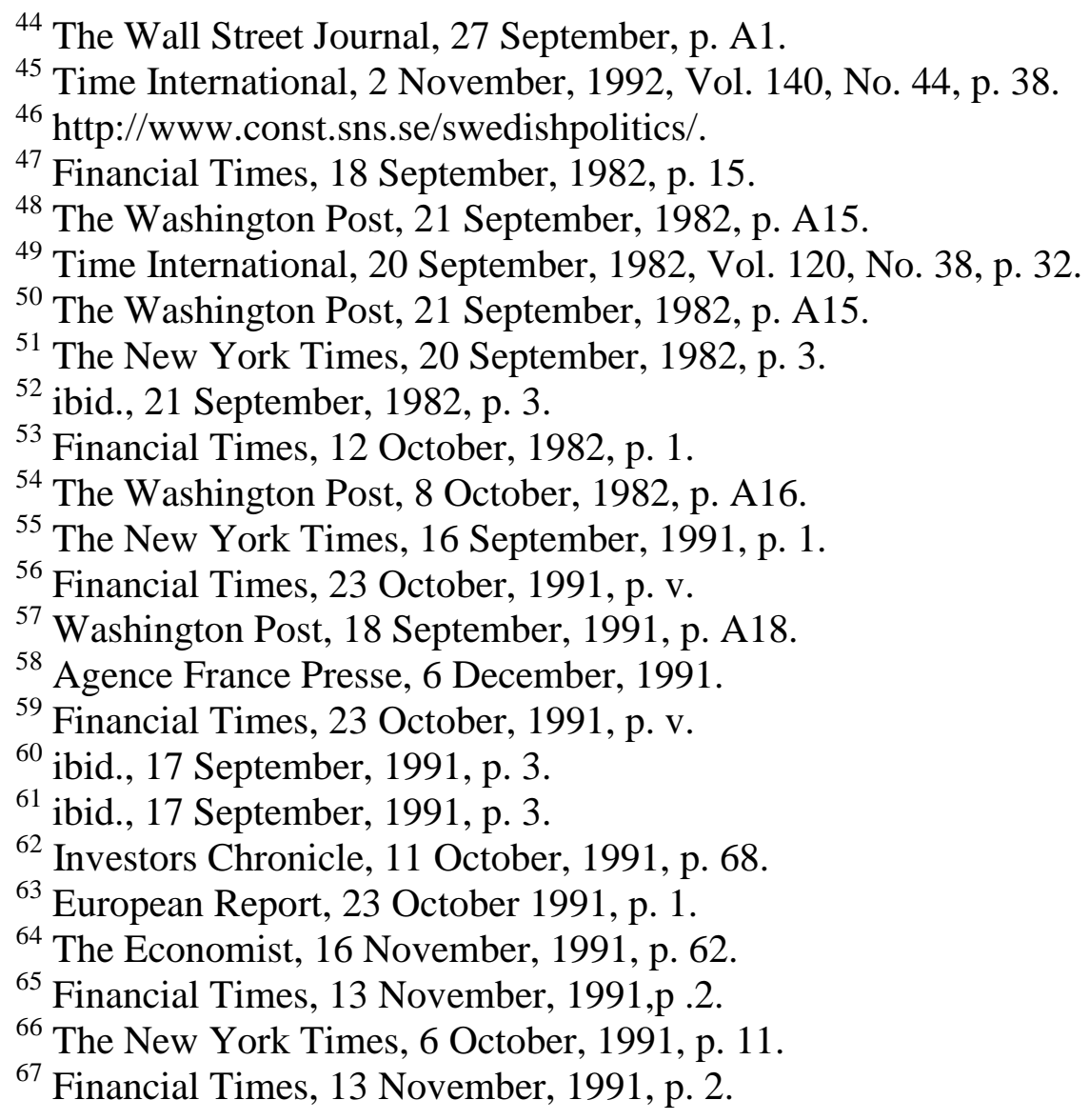

\section{References}

Ahlén, Kristina. 1989. "Swedish Collective Bargaining Under Pressure: Inter-union

Rivalry and Incomes Policies.” British Journal of Industrial Relations 23: 3: 330346.

Berg, A., and C. Pattillo. 1999. "Predicting Currency Crises: The Indicators Approach and an Alternative." Journal of Money and Finance 18: 561-586.

Berman, Sheri. 1998. The Social Democratic Moment: Ideas and Politics in the Making of Interwar Europe. Cambridge, MA: Harvard University Press. 
Blyth, Mark. 1997. "Moving the Political Middle: Redefining the Boundaries of State Action." The Political Quarterly 68: 3: 217-314.

Blyth, Mark. 2001. "The Transformation of the Swedish Model: Economic Ideas, Distributional Conflict and Institutional Change.” World Politics 54: 1: 1-26.

Blyth, Mark. 2002. Great Transformations: Economic Ideas and Institutional Change in the Twentieth Century. Cambridge: Cambridge University Press.

Caple, James. 1991. The US Economy - Timing the Turning-Point. London: The Securities and Futures Authority.

Casper, Gretchen, and Michelle M. Taylor. 1996. Negotiating Democracy: Transitions from Authoritarian Rule. Pittsburgh: University of Pittsburgh Press.

Christensen, T. 1997. "Utviklingen av direktoratene - aktører, tenkning og organisasjons-former." In Forvaltningskunnskap, eds. T.Christensen and M.Egeberg. Oslo: Tano.

Clemens, Elizabeth S., and James M. Cook. 1999. "Politics and Institutionalism: Explaining Durability and Change." Annual Review of Sociology 25: 441-466.

Clinton, Bill. 1992. Putting People First: A National Economic Strategy for America. Little Rock, AK: The Clinton for President Committee. 
Collier, R. B., and D. Collier. 1991. Shaping the Political Arena: Critical Junctures, the Labour Movement, and Regime Dynamics in Latin America. Princeton, NJ: Princeton University Press.

Collier, David. 1997. "Comparative Method in the 1990s." APSA-CP: Newsletter of the APSA Organised Section in Comparative Politics 9: 1: 1-5.

Cortell, Andrew P., and Susan Peterson. 1999. “Altered States: Explaining Domestic Institutional Change.” British Journal of Political Science 29: 177-203.

Dahl, Robert. 1961. Who Governs? Democracy and Power in an American City. New Haven, CT: Yale University Press.

Dark, Taylor E. 1999. The Unions and the Democrats: An Enduring Alliance. London: Ithaca.

De Geer, Hans. 1992. The Rise and Fall of the Swedish Model. Chichester: Garden Publications.

D’Souza, Dinesh. 1997. Ronald Reagan: How an Ordinary Man Became an Extraordinary Leader. New York: The Free Press.

Fearon, James D. 1991. "Counterfactuals and Hypothesis Testing in Political Science.” World Politics 43: 577-592. 
Fearon. James D. 1996. "Causes and Counterfactuals in Social Science: Exploring an Analogy Between Cellular Automata and Historical Processes.” In Counterfactual Thought Experiments in World Politics, eds. Philip E. Tetlock and Arron Belkin. Princeton: Princeton University Press.

French, Michael. 1997. US Economic History Since 1945. Manchester: Manchester University Press.

Gal, John, and David Bargal. 2002. "Critical Junctures, Labour Movements and the Development of Occupational Welfare in Israel.” Social Problems 49: 3: 432-454.

Garrett, Geoffrey. 1993. "The Politics of Structural Change: Swedish Social Democracy and Thatcherism in Comparative Perspective." Comparative Political Studies 25: 4: 521-547.

Garrett, Geoffrey, and Peter Lange. 1995. "Internationalization, Institutions, and Political Change.” International Organization 49: 4: 627-655.

Garuba, Dauda S. 2006. "Survival at the Margins: Economic Crisis and Coping Mechanisms in Rural Nigeria.” Local Environment 11:1: 17-36

Golob, Stephanie. 2003. "Beyond the Policy Frontier: Canada, Mexico, and the Ideological Origins of NAFTA." World Politics 55: 3: 361-398. 
González, Sara, 2005. "The Politics of the Economic Crisis and Restructuring in the Basque Country and Spain During the 1980s." Space and Policy 9: 2: 93-112.

Gorges, M. J. 2001. "The New Institutionalism and the Study of the European Union: The Case of the Social Dialogue." West European Politics 24: 4: 152-168.

Greener, Ian. 2001. "Social Learning and Macroeconomic Policy in Britain." Journal of Public Policy 21: 133-152.

Hadenius, Stig. 1997. Swedish Politics During the $20^{\text {th }}$ Century - Conflict and Consensus. Stockholm: Svenska Institute.

Haggard, Stephan. 1988. “The Institutional Foundations of Hegemony: Explaining the Reciprocal Trade Agreements Act of 1934." International Organization 42: 1: 91-119.

Hall, Peter A. 1989. The Power of Economic Ideas. Princeton, NJ: Princeton University Press.

Hall, Peter A. 1993. "Policy Paradigms, Social Learning, and the State: The Case of Economic Policy making in Britain." Comparative Politics 25: 3: 275-296.

Hay, Colin. 1999. "Crisis and the Structural Transformation of the State: Interrogating the Process of Change." The British Journal of Politics and International Relations 1: 3: 317-344. 
Heath, Jim F. 1975. Decade of Disillusionment: The Kennedy-Johnson Years. Bloomington: Indiana University Press.

Hogan, J. W. 2005. “Testing for a Critical Juncture: Change in the ICTU's Influence over Public Policy in 1959." Irish Political Studies 20: 3: 23-43.

Hogan, J. W. 2006. "Remoulding the Critical Junctures Approach.” Canadian Journal of Political Science 39: 3: 657-679.

Jones, Maldwyn A. 1995. The Limits of Liberty: American History 1607 - 1992. ( $2^{\text {nd }}$ ed.) Oxford: Oxford University Press.

Kaminsky, G. L., S. Lizondo, and C. Reinhart. 1998. "Leading Indicators of Currency Crises." International Monetary Fund Staff Papers 45: 1-48.

Karl, Terry Lynn. 1997. The Politics of Plenty: Oil Booms and Petro-States. Berkeley: University of California Press.

Kingdon, John. 1995. Agendas, Alternatives, and Public Policy. (2nd ed.) New York: Harper.

Krugman, Paul A. 1990. The Age of Diminished Expectations: US Economic Policy in the 1990s. Cambridge, MA: MIT Press. 
Kwon, Soonman, 2001. "Economic Crisis and Social Policy Reform in Korea." International Journal of Social Welfare 10: 2: 97-106.

Legro, Jeffrey W. 2000. "The Transformation of Policy Ideas.” American Journal of Political Science 44: 3: 419-432.

Levy, Jack S. 1994. "Learning and Forign Policy: Sweeping a Conceptual Minefield.” International Organisation 48: 279-312.

Lijphart, Arend. 1999. Patterns of Democracy: Government Forms and Performance in Thirty-six Countries. New Haven, Conn: Yale University Press.

Mahoney, James. 2000. "Path Dependence in Historical Sociology." Theory and Society 29: 4: 507-548.

Mahoney, James. 2001. "Path Dependent Explanations of Regime Change: Central America in Comparative Perspective." Studies in Comparative International Development 36: 1: 111-141.

Mahoney, James. 2003. "Long-Run Development and the Legacy of Colonialism in Spanish America." American Journal of Sociology 109: 1: 50-106.

Marshall, Mike. 1996. "The Changing Face of Swedish Corporatism: The Disintegration of Consensus.” Journal of Economic Policy 30: 3: 843-858. 
Martin, A. 2000. “The Politics of Macroeconomic Policy and Wage Negotiations in Sweden." In Unions, Employers, and Central Banks, eds. Torben Iversen, Jonas Pontussson, and David Soskice. New York: Cambridge University Press.

McNamara, Kathleen R. 1998. The Currency of Ideas: Monetary Politics in the European Union. Ithaca: Cornell University Press.

Mitchell, R.B. 1993. International Historical Statistics: Europe 1750-1998. (3 ${ }^{\text {rd }}$ ed.) Hong Kong: Stockton Press.

Mitchell, R.B. 1998. International Historical Statistics: The Americas 1750-1993. (4th ed.) Basingstoke: Macmillan.

Oliver, Michael J. and Hugh Pemberton. 2004. "Learning and Change in 20thCentury British Economic Policy.” Governance 17: 3: 415-441.

Organisation for Economic Cooperation and Development. 1982. Sweden 1982. Paris: OECD.

Organisation for Economic Cooperation and Development. 1984. Sweden 1984. Paris: OECD.

Organisation for Economic Cooperation and Development. 1992. Sweden 1992. Paris: OECD. 
Organisation for Economic Cooperation and Development. 1962. The United States of America 1962. Paris: OECD.

Organisation for Economic Cooperation and Development. 1982. The United States of America 1982. Paris: OECD.

Organisation for Economic Cooperation and Development. 1993. The United States of America 1993. Paris: OECD.

Pei, Minxin and Ariel David Adesnik. 2000. “Why Recessions Don't Start Revolution." Foreign Policy 118: 138-151.

Pemberton, Hugh. 2000. "Policy Networks and Policy Learning: UK Economic Policy in the 1960s and 1970s." Public Administration 78: 4: 771-792.

Pierson, Paul. 1993. "When Effects Become Cause: Policy Feedback and Political Change." World Politics 45: 4: 595-628

Pierson, Paul. 2000. "Increasing Returns, Path Dependency, and the Study of Politics." American Political Science Review 94: 2: 251-267.

Pierson, Paul. 2004. Politics in Time: History, Institutions, and Social Analysis. Princeton University Press: Princeton, NJ. 
Pierson, Paul and Theda Skocpol. 2002. "Historical Institutionalism in Contemporary Political Science.” unpublished paper: 1-33.

Sheingate, A. D. 2003. "Political Entrepreneurship, Institutional Change, and American Political Development." Studies in American Political Development 17: $185-203$.

Siven, Claes-Henric. 1984. 'The Political Economy of Sweden in the 1970s." Department of Economics - University of Stockholm, Research Papers in Economics, No. 1.

Solimano, A. 2005. Political Crises, Social Conflict and Economic Development: The Political Economy of the Andean Region. Cheltenham: Edward Elgar

Steinmo, Sven. 1989. "Political Institutions and Tax Policy in the United States, Sweden, and Britain.” World Politics 41: 4: 500-535.

Stone, D. A. 1989. "Causal Stories and the Formation of Policy Agendas." Political Science Quarterly 104: 2: 281-300.

Streeck, Wolfgang and Kathleen Thelen. 2005. "Introduction: Institutional Change in Advanced Political Economies." In Beyond Continuity. Institutional Change in Advanced Political Economies, eds. Kathleen Thelen and Wolfgang Steeck. Oxford: Oxford University Press. 
Thelen, Kathleen, and Sven Steinmo. 1992. "Historical Institutionalism in Comparative Politics." In Structuring Politics: Historical Institutionalism in Comparative Analysis, eds. Sven Steinmo, Kathleen Thelen, and Frank Longstreth. Cambridge: Cambridge University Press.

Thelen, Kathleen. 1999. "Historical Institutionalism in Comparative Politics." Annual Review of Political Science 2: 369-404.

Thelen, Kathkeen. 2000. "Timing and Temporality in the Analysis of Institutional Evolution and Change." Studies in American Political Development 14: 1: 102-109.

Thelen, Kathleen. 2004. How Institutions Evolve: The Political Economy of Skills in Germany, Britain, the United States and Japan. Cambridge: Cambridge University Press.

Tilly, C. 1975. The Formation of Nation States in Western Europe. Princeton, NJ: Princeton University Press.

Vargas, Vicente. 2004. “The Political Dynamic of the Conflict in Chiapas: A History of its Critical Junctures." Paper presented at Centre of Latin American Studies research day, University of Cambridge.

Walsh, J. I. 2006. "Policy Failure and Policy Change: British Security Policy After the Cold War." Comparative Political Studies 39: 490-518. 
Wayne, Stephen J. 1992. The Road to the White House 1992: The Politics of Presidential Elections. New York: St. Martin’s Press.

Yu, L., Lai, K. K., and Wang, S-Y. 2006. "Currency Crisis Forecasting with General Regression Neural Networks." International Journal of Information Technology and Decision Making 5: 3: 437-454. 